\title{
Research on the Implementation of Stratified Teaching of Public English in Vocational Colleges
}

\author{
Nuan Wang \\ Changchun Automobile Industry Institute, Jilin Province, China.
}

173265523@qq.com

Keywords: Vocational Colleges Public English Stratified Teaching

\begin{abstract}
As the reform of public English teaching in vocational colleges in China, the credit hours of public English in vocational colleges have been shortened greatly. But many vocational colleges still require teachers to achieve the teaching efficiency in the past and improve the students' public English abilities steadily. It is a big problem that public English teaching in vocational colleges is facing now. Moreover, vocational students' English knowledge is at different levels, and many of them come from villages and towns in China. This makes the teaching tasks of public English very difficult. Under such background and teaching environment, the vocational public English classes began to implement stratified teaching. This article inquires overtly stratified teaching pattern and covertly stratified teaching pattern of public English in vocational colleges and even the pros and cons of each pattern. The author hopes that through this research, public English teachers can help the students activate potential of English, and help students improve their English.
\end{abstract}

\section{Introduction}

English, as an international language, has always been popular with students. But in recent years, the country has begun to reform the English teaching patterns of colleges and universities. The specific measures include: weakening the importance of Practical English Test (PET), English test certificate is no longer associated with the diploma, the public English class hours are shortened and so on. But as a communication tool, English still has importance for the future career development of students. In particular, many vocational colleges' students will enter to the joint ventures as technicians after graduation. They may have chances to communicate with foreign staff, read and translate English instruction manuals and face other language problems. Translation software can not satisfy their communication needs. Most of the students in vocational colleges come from underdeveloped areas in China, such as villages and towns, where English teaching conditions are very limited. That's why the English abilities of the students in vocational colleges are so poor. In the face of such situation, it is a difficult problem for public English teachers to carry out their teaching patterns in accordance with the students' aptitude. Many vocational colleges and universities have begun to explore the stratified teaching patterns of public English, aiming at meeting the learning needs and improvement of students in different language levels.

\section{Introduction of Overtly Stratified Teaching Pattern of Public English}

Many vocational colleges have already tried to implement the overtly stratified teaching pattern in English teaching by dividing the students into different English classes according to the students' scores. The statistics of English scores is realized by analyzing their entrance scores or organizing English proficiency tests. In general, colleges would keep the administrative classes unchanged, only divide the English classes into different levels. The benefit of doing so is to divide students 
with similar abilities into one class, which is easy for English teachers to teach and assess. But the overtly stratified teaching pattern cannot persist long because it is difficult to achieve in the whole college. If so, all English classes need to be taught at the same time, so the college has to have enough English teachers, and there will be a lot of difficulties in teaching organization and scheduling. It is difficult for all English classes to be assessed with the same standards. In addition, students tend to be self-abased and give up themselves as hopeless. Take the author's vocational college as example: the college used to try the overtly stratified teaching pattern of public English classes, but English teachers found it difficult to practice in the whole college. This year, the college tried to select some excellent students to form one class (we call it "Advanced Class") in the whole school to practice the overtly stratified teaching pattern, and it is very easy to achieve the teaching objectives. Therefore, the overtly stratified teaching pattern is more suitable in small scale, but it's difficult to implement it in the whole college in the long run.

\section{The Present situation of Public English Teaching and Students in Vocational Colleges}

\section{The Advantages of Covertly Stratified Teaching of Public English}

Many vocational colleges have tried overtly stratified teaching in public English classes in the past few years. But they all quit it. However, the author recommends that public English should carry out covertly stratified teaching instead of overtly one, because its controllability is higher than that of overtly stratified teaching. What's more, it is easy to carry out covertly stratified teaching activities in the whole college. Covertly stratified teaching has advantages in improving students' communication abilities and language knowledge. The psychological factor of a student is one of the determinants of his/her learning state. Covertly stratified teaching can avoid the bad influence of overtly one on students. For example, while still kept in the same class, during the oral English training, communication practice and group discussion, only the teacher knows that the students are stratified. Students can speak freely in groups as usual and will not show their inferiority any more. Learning, exploration, sharing, mutual assistance, features of English learning process, can be reflected in the covertly stratified teaching.

\section{The Faculty Structure of Vocational Colleges}

In recent years, vocational colleges and universities have made more efforts to construct the faculty structures. They have set strict recruitment standards in order to employ more and more excellent English teachers. An increasing number of vocational English teachers have got master's degrees or doctor's degrees. Most of vocational English teachers are young, about 30 to 40 years old. They are not only active, energetic and assiduous, but also excellent in many aspects, such as professional abilities, personal qualities, practice abilities and so on. Their age and educational background enable them to accept the reform of English teaching quickly. Young teachers are willing to dedicate themselves to the reform and development of vocational education. At the same time, they have a deep sense of responsibility and mission, making them know every student's state of language learning very well.

\section{Informatization Means in Covertly Stratified Teaching of Public English}

There have been substantial improvements in the conditions of vocational colleges. With the assistance of multimedia classrooms, vocational English teachers can carry out covertly stratified teaching. Internet access in multimedia classrooms provides English teachers with technical support and informatization platform. Besides multimedia classrooms, other network technical conditions have also been improved recently. Take the statistics of the author's school as an example, $100 \%$ of the classrooms in the school are equipped with multimedia teaching equipment, $100 \%$ of the 
dormitory can be connected to the Internet, and the network coverage rate of the classrooms is about $94 \% .100 \%$ of students own smart phones, and $87.4 \%$ of students have personal computers or mobile terminals. In public English classes, $80 \%$ of English teachers would like to use multimedia. Half of English teachers often use language labs to practice students' oral English and listening activities, and $15 \%$ of them begin to use mobile devices, such as mobile phones and pads, for teaching. The data above shows that the development of Internet and the popularization of multimedia teaching have been fully utilized by vocational English teachers. When implementing covertly stratified teaching of public English, vocational English teachers could take the power of multimedia and Internet into account. Informatization and the Internet should be considered as one of the teaching methods to carry out covertly stratified teaching.

\section{The Application Examples of Informatization in Covertly Stratified Teaching}

\section{Covert Stratification in the Teaching Objectives and Teaching Contents}

Before starting covertly stratified teaching, the teacher will investigate and analyze the students' learning situation in the class in order to stratify the students in the teacher's mind covertly. The teaching contents should be suitable for students of different levels. While teaching in the class, English teachers could ask creative and innovative questions for students with strong learning ability, and also set up simple and basic questions for students who should consolidate their English foundations.

2. The Use of Multimedia Classrooms and Language Labs

As a compulsory course for vocational students, public English, which is the consolidation of specialized courses, needs to follow the enterprise needs and development. In the process of covertly stratified teaching, English teachers could take full advantage of language labs, which are convenient for teachers to conduct multimedia teaching demonstrations. On the one hand, public English course may use language labs for oral and listening training, because in language labs each student can make one-on-one conversations with the teacher, or do tasks in pairs, or training in groups. All the seats there are numbered, having independent space. Comparing with the traditional classroom teaching, language labs allow the students with poor communicative competence speaking English freely. If been answer questions in the traditional classroom, the student would be highlighted, which might make him feel awkward. On the other hand, the exercises of oral and listening training are easier to control in language labs. By using the software, the teacher could divide the students in the same language level into a group, sending them a task which is coherence with their language abilities; or the teacher could divide the students in different language levels into a group, sending them a task which could be performed by mutual aid in the group. This is a practice method of covertly stratified teaching according to different students' abilities.

\section{New Teaching Resources: Micro-courses And MOOCs}

In recent years, micro-courses and MOOCs have been popular and promoted in vocational colleges. Online courses and micro-courses are suited for the stratified teaching of public English. English teachers could analyze students' grades and requirements at the beginning of the semester, and then according to covertly stratified situation, English teachers could choose micro-courses or MOOCs for students in different levels in order to meet their after-school learning needs. These new teaching resources could be the supplement of traditional classroom teaching. At the same time, they could strengthen the students' basic knowledge, extend the students' knowledge and improve their language abilities. As regards grammar and vocabulary, teachers can use micro-courses to explain more directly and carefully. Through the method of on-line learning, students can make use 
of their spare time effectively. Not only can the students' learning time be ensured, but also knowledge and exercise can be guaranteed.

4. The Application of Informatization in Covertly Stratified Teaching

There is a lot of new teaching software, which can be integrated into classroom teaching. The use of informatization in teaching can help realize covertly stratified teaching in the class. Here are some examples.

(1) The website: www.wjx.cn

This website can do questionnaires, which can help English teachers carry out initial researches on the students' situation in the class, and understand the students' learning needs. Through investigation and research, teachers can understand the students' English levels clearly, and implement covertly stratified teaching rapidly. According to the feedback questionnaire, teachers will set different teaching contents for students in different English levels so that the covertly stratified teaching can be developed inside the class smoothly.

(2) The Teaching Quality Management Platform: MYCOS

Take the author's college for example. The college has introduced MYCOS, a teaching quality management platform, which can help English teachers get the feedback information from the students anytime and anywhere. Students can use MYCOS to estimate the teacher's teaching organization, teaching contents, teaching activities, etc. By analyzing the feedback data, English teacher can adjust the implementation of covertly stratified teaching and control progress of teaching.

(3) The Software : Rain Classroom

Rain Classroom is new software designed by Tsinghua University of China. It can be used for preview, online learning, review, and sharing of high-quality teaching resources. English teachers can carry out covertly stratified teaching by dividing students in a class into three levels: A (excellent), B (average), and C (weak). As for Level C (weak students), the teacher can use Rain Classroom to send pre-class content to the students' mobile phones, and then the students can browse it in order to consolidate the basic knowledge; for Level A and B (excellent or average students), if the pre-class content is too simple, they could choose to browse it or not; during the teaching, Rain Classroom can allow the students' mobile phones doing real-time synchronization with the teacher's PPT. If there is anything difficult, students can click on the button "I don't understand" right away. The teacher will have real-time feedback and know what the students do not understand, which levels the students are in. the teachers will inquire and explore the reasons why the students do not understand, adjust the teaching method, or tutor them after class; After school, the teacher can use Rain Classroom to send videos, exercises, audios and other learning resources associated with the teaching contents. For Level A and B, face-to-face teaching time is limited, but this link will be able to make supplement to the teaching contents. The learning desire of them can be satisfied.

\section{Conclusion}

Both overtly and covertly stratified teaching modes have advantages and disadvantages. There are many difficulties in implementing overtly stratified teaching of public English in a large scale. But it can be carried out in a small scale. Most of classes would better implement covertly stratified teaching in the whole college. Vocational English teachers can use various forms of informatization techniques to help practice covertly stratified teaching so as to promote the teaching reform of public English education in vocational colleges. 


\section{References}

[1] Nuan Wang. The Exploration and Practice of the Teaching Mode of Public English in Vocational Colleges -- Taking Changchun Automobile Industry Institute for Example [J].School Education, 2016(14):95.

[2] Chunfeng Lin. Study on the Hierarchical Teaching of Public English in Vocational Colleges in Guangxi [J].Education and Career, 2013(3):92-93.

[3] Yong Song. Research on the Application of Stratified Teaching in English [J]. Overseas English, 2011(5):106-107.

[4] Xiaoxia Mu. A Brief Discussion on the Hierarchical Teaching of Vocational English [J]. Western China Technology, 2011(11):85-86. 